\title{
Selected Features of Canadian Goldenrod That Predispose the Plant to Phytoremediation
}

\author{
Aleksandra Bielecka ${ }^{1 *}$, Elżbieta Królak ${ }^{1}$ \\ ${ }^{1}$ Siedlce University of Natural Sciences and Humanities, Institute of Biology, Prusa 12, 08-110 Siedlce, Poland \\ * Corresponding author's e-mail: aleksandrab@onet.eu
}

\begin{abstract}
Solidago canadensis (Canadian goldenrod) is an invasive plant species occurring in Poland. Canadian goldenrod tolerates a wide range of habitat conditions, it grows in landfills and soils contaminated with heavy metals. The paper presents the selected biometric features of the plant which indicate the possibility of its use for phytoremediation purposes. The analysis was based on the results of own research and literature data. The biometric features of the plant chose for the research are: aboveground biomass (which reaches about 4.4 tons d.m/ha on a surface covered with the plant in more than 70\%), the possibility of annual collection of the aboveground parts and their use for energy purposes, extensive roots and rhizomes system ensuring soil stabilization, high accumulation of some metals in the underground parts of the plant.
\end{abstract}

Keywords: aboveground biomass, underground biomass, phytostabilization, Solidago canadensis

\section{INTRODUCTION}

Various plant species are used in the phytoremediation processes to treat soil contaminated with heavy metals [Laghlimi et. al. 2015]. The selection of plants for phytoremediation depends e.g. on the type and depth of soil contamination. The plants which are frequently used for this purpose tolerate high levels of heavy metals in the soil. They easily take up metals from the soil and either stabilize them in roots or relocate them to their aboveground parts. The plants are characterized by rapid growth, high biomass and ease of collection [Kabała et al. 2010, Laghlimi et al. 2015, Salt et al. 1995, Susarla et al. 2002]. Although the list of plant species used in phytoremediation is long, there is still the need to identify new species which have the ability to remove heavy metals from the soil and can be used for industrial purposes [Laghlimi et al. 2015]. The significance of seasonal flowering plants is often emphasized in phytoremediation. Annual or seasonal harvest of their aboveground parts contributes to the systematic removal of metals from the soil [Sinha et al. 2013]. In phytoremediation, it is also reasonable to use the species that overgrow various habitats, e.g. mining dumps or industrial waste dumps [Thangavel and Subhuram 2004].

The Canadian goldenrod (Solidago canadensis L.) is the plant that has recently received much attention because of its invasive nature. The native range of the goldenrod is North America [Weber and Jacobs 2005]. In Europe and Asia, S. canadensis is quickly entering new areas [Huang and Guo 2005]. This species tolerates a wide range of habitat conditions [Huang et al. 2007, Jin et al. 2004, Szymura and Wolski 2006]. It also shows high tolerance to heavy metals contamination [Huang et al. 2007, Xiang et al. 2010]. It occurs in abandoned arable fields [Rola and Rola 2010, Szymura and Wolski 2006], as well as in post-industrial wastelands [Antonijevic et al. 2012, Nowińska et al. 2012, Vega et al. 2004]. In the places of occurrence, especially in anthropogenic habitats, it forms extensive and compact fields [Holeksa et al. 2015, Szymura and Wolski 2006]. S. canadensis is a perennial plant. Every year, it produces aboveground ramets and underground rhizomes. Individual clones form dense clusters, depending on the age of the maple, 
composed of many ramets. Canadian goldenrod also reaches high aboveground biomass, estimated at about 7.7 tones of fresh matter per ha, with over $70 \%$ coverage of the area [Jezierska-Domaradzka and Domaradzki 2012]. The plant has an extensive root and underground rhizomes system. The roots diverge to the base of the ramets and reach a depth of at least $20 \mathrm{~cm}$ [Weber 2000].

The information on selected goldenrod features that predispose it as a plant that could be used in phytoremediation of the soils contaminated with heavy metals is poorly recognized. The purpose of this paper is to analyze the selected goldenrod features that predispose the plant for phytoremediation purposes. The analysis was based on the literature data and own research, covering the selected biometric features of $S$. canadensis occurring in two locations in Poland, differing in the time of occurrence of the goldenrod.

\section{MATERIAL AND METHODS}

The plant for study was collected in the locations in Poland situated about $350 \mathrm{~km}$ from each other: Siedlce $\left(52^{\circ} 10^{\prime} \mathrm{N}, 22^{\circ} 17^{\prime} \mathrm{E}\right)$ and Olkusz (50 $\left.16^{\prime} \mathrm{N}, 19^{\circ} 33^{\prime} \mathrm{E}\right)$. In the last decade, $S$. canadensis began to appear massively in the vicinity of Siedlce [Rzymowska 2015]. In the vicinity of Olkusz, numerous sites of $S$. canadensis were recorded as early as in the 1980s [Guzikowa and Maycook 1986, Holeksa et al. 2015].

At each location, 25 sites were randomly selected for the study. The stands where the goldenrod occurred occupied an area of at least $500 \mathrm{~m}^{2}$. Three plots $(3 \times 3 \mathrm{~m})$ were selected at each site. The goldenrod samples were cut out of each selected plot using a $0.16 \mathrm{~m}^{2}$ frame, and then the underground parts of the plant, containing rhizomes and roots, were dug from a depth of up to $20 \mathrm{~cm}$. In the field, the degree of coverage of a selected position with the goldenrod, the density of ramets and the length of cut ramets were measured. A representative sample of the aboveground parts of the plant (20 ramets) was taken from each plot. In the laboratory, the aboveground parts of the plant, i.e. leaves, stems and inflorescences, were separated from each other. The fresh mass was determined, and then the dry mass was determined by drying at $60^{\circ} \mathrm{C}$. The percentage share of leaves, stems and inflorescences in the dry matter of the plant was calculated. The underground parts of the plant were washed thoroughly under running water, and then rinsed in distilled water. The rhizomes were separated from the roots. After drying at $60^{\circ} \mathrm{C}$, the weight of rhizomes and roots was measured and the percentage of rhizomes in the underground parts of the plant was determined.

The normality of data was tested using the Shapiro-Wilk test. In order to compare the values of the measured parameters in the samples collected in Siedlce and Olkusz, the Mann-Whitney test (not normally distributed data) or t-test (normally distributed data) were used.

\section{RESULTS AND DISCUSSION}

The average percentage cover of $S$. canadensis of the studied sites was about $70 \%$ and the density of ramets per $\mathrm{m}^{2}$ of the surface varied within the range of 12-89 (Table 1). These parameters were significantly correlated $(\mathrm{R}=0.67, \mathrm{p}<0.001)$ (Fig. 1).

The mean dry biomass of the aboveground parts of $S$. canadensis per 1 ramet was above $10 \mathrm{~g}$ and of underground parts - about $7 \mathrm{~g}$ (Table 1). There were no significant differences in the mass of aboveground and underground parts of $S$. canadensis in the two studied locations.

In both locations, among the aboveground parts of the plant, stems corresponded to about $54 \%$ of the ramet biomass. The average percentage share of leaves and inflorescences was comparable and amounted to slightly over $20 \%$. Among the underground parts, rhizomes constituted the dominant share in biomass in the two locations (Table 2).

There were no significant relationships ( $p>0.05)$ between the dry mass of the aboveground and underground parts of the goldenrod and the density of ramets $(\mathrm{R}=-0.05$ and $\mathrm{R}=-0.06$, respectively) and between the dry mass of the aboveground and underground parts and the percentage cover of plots with the goldenrod ( $R$ $=-0.06$ and $\mathrm{R}=-0.07)$. There was also no significant correlation between the height of ramets and the density $(\mathrm{R}=0.17)$ as well as the height of ramets and the percentage coverage $(R=0.15)$.

The mass of 1 ramet and the density of ramets on the plots were taken into account to calculate the goldenrod biomass per $1 \mathrm{~m}^{2}$ (Table 3). The fresh mass of the aboveground parts varied in the range $119-2735 \mathrm{~g} / \mathrm{m}^{2}$, the dry biomass of the aboveground parts ranged from 50.9 to $1136 \mathrm{~g} / \mathrm{m}^{2}$ and the dry biomass of underground parts was in the range 


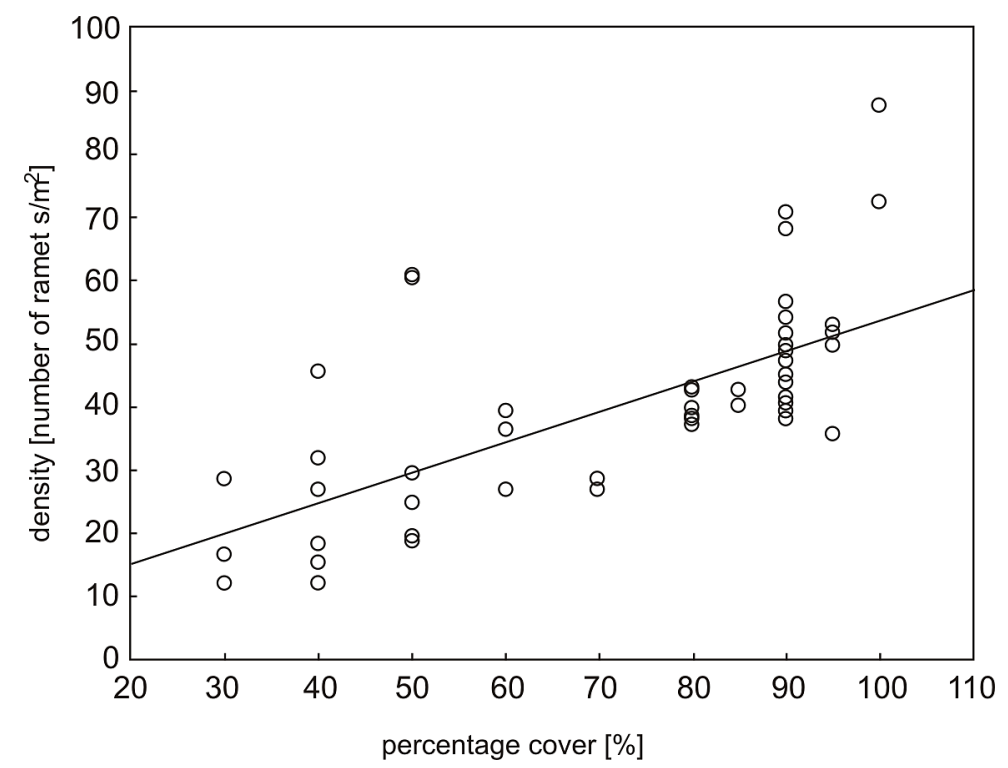

Fig. 1. Correlation between percentage cover and density of ramets of Solidago canadensis

Table 1. The mean values \pm SD and the range of measured parameters: percentage cover, density, height of ramets, dry mass of the aboveground and underground parts calculated for 1 ramet of Solidago canadensis in Siedlce and Olkusz

\begin{tabular}{|c|c|c|c|c|c|}
\hline \multicolumn{2}{|c|}{ Parameter } & Unit & Siedlce & Olkusz & Values of statistiacal tests \\
\hline \multicolumn{2}{|c|}{ Percentage cover } & $\%$ & $\begin{array}{c}72.2 \pm 24.1 \\
(30-100) \\
\end{array}$ & $\begin{array}{c}72.8 \pm 23.1 \\
(30-95) \\
\end{array}$ & $Z=0.32, p=0.75$ \\
\hline \multicolumn{2}{|l|}{ Density } & $\begin{array}{l}\text { number of } \\
\text { ramets } / \mathrm{m}^{2}\end{array}$ & $\begin{array}{l}45 \pm 18.3 \\
(15-89)\end{array}$ & $36 \pm 12.3(12-54)$ & $t=2.03, p=0.048, d f=48$ \\
\hline \multicolumn{2}{|c|}{ Height of ramet } & $\mathrm{cm}$ & $\begin{array}{c}121.4 \pm 28.6 \\
(35-193)\end{array}$ & $\begin{array}{c}116.6 \pm 28.9 \\
(39-198) \\
\end{array}$ & $\mathrm{t}=4.604, \mathrm{p}<0.001, \mathrm{df}=3095$ \\
\hline \multirow{2}{*}{$\begin{array}{l}\text { Dry mass of } \\
\text { parts }\end{array}$} & aboveground & \multirow{2}{*}{$\mathrm{g} /$ ramet } & $\begin{array}{c}10.4 \pm 4.2 \\
(2.73-19.2)\end{array}$ & $\begin{array}{c}11.9 \pm 2.6 \\
(8.45-16.9)\end{array}$ & $t=1.59, p=0.12, d f=48$ \\
\hline & underground & & $\begin{array}{l}7.28 \pm 2.18 \\
(3.5-13.0)\end{array}$ & $\begin{array}{c}6.3 \pm 2.8 \\
(2.33-13.3)\end{array}$ & $\begin{array}{l}t=1.33, p=0.19 \\
d f=48\end{array}$ \\
\hline
\end{tabular}

Table 2. Percentage of individual morphological parts in dry biomass of Solidago canadensis in aboveground and underground parts per 1 ramet

\begin{tabular}{|l|l|l|l|l|}
\hline \multicolumn{2}{|c|}{ Parts of plant } & \multicolumn{1}{c|}{ Siedlce } & \multicolumn{1}{c|}{ Olkusz } & \multicolumn{1}{c|}{$\mathrm{t}$-test values } \\
\hline \multirow{4}{*}{ Aboveground parts } & Stems & $54.1 \pm 5.42$ & $54.5 \pm 6.22$ & $\mathrm{t}=0.25, \mathrm{p}=0.81$ \\
\cline { 2 - 5 } & Leaves & $23.7 \pm 4.94$ & $24.4 \pm 5.90$ & $\mathrm{t}=0.47, \mathrm{p}=0,64$ \\
\cline { 2 - 5 } & Inflorescenses & $22.2 \pm 4.22$ & $21.1 \pm 5.00$ & $\mathrm{t}=0.87, \mathrm{p}=0.39$ \\
\hline \multirow{2}{*}{ Underground parts } & Rhizomes & $68.2 \pm 6.40$ & $72.2 \pm 10.9$ & $\mathrm{t}=1.59, \mathrm{p}=0.12$ \\
\cline { 2 - 5 } & Roots & $31.8 \pm 6.40$ & $27.8 \pm 10.9$ & $\mathrm{t}=1.59, \mathrm{p}=0.12$ \\
\hline
\end{tabular}

$32.8-564.4 \mathrm{~g} / \mathrm{m}^{2}$. There were no differences in the aboveground and underground goldenrod biomass calculated per $1 \mathrm{~m}^{2}$ of area in the two locations.

The results for the biomass of the aboveground parts of Solidago canadensis obtained for our study are about 1 ton higher than the values measured by Jezierska-Domaradzka and Domaradzki [2012]. The authors harvested the aboveground parts of the goldenrod before the flowering period. For our research, the samples were taken during the period of intensive flowering of the plant.
The share of inflorescences in the biomass of the aboveground parts of $S$. candensis was above $20 \%$, which is about 1 ton d.m./ha. The inflorescence biomass probably determined the larger results. The goldenrod biomass obtained for our study is comparable to e.g. the biomass of Calamagrostis epigejos [Grzelak et al. 2016] and about a half of the biomass of e.g. Miscanthus giganteus, Helianthus tuberosus or Sida hermaphrodita [Kabała et al. 2010] (Table 4). The listed plant species, in addition to their use in phytoremediation of soils 
Table 3. Fresh and dry mass of aboveground and dry mass of underground parts of Solidago canadensis calculated per $1 \mathrm{~m}^{2}$

\begin{tabular}{|l|c|c|c|c|}
\hline \multicolumn{1}{|c|}{ Parameter } & Unit & Siedlce & Olkusz & $\begin{array}{c}\text { Mann-Whitney } \\
\text { test values }\end{array}$ \\
\cline { 1 - 4 } Fresh mass of aboveground parts & & $\begin{array}{c}1034 \pm 605.8 \\
(119-2735)\end{array}$ & $\begin{array}{c}999 \pm 485 \\
(251-2274)\end{array}$ & $\mathrm{Z}=0.31, \mathrm{p}=0.76$ \\
\cline { 1 - 4 } Dry mass of aboveground parts & \multirow{2}{*}{$\mathrm{g} / \mathrm{m}^{2}$} & $\begin{array}{c}473 \pm 273 \\
(50.9-1136)\end{array}$ & $\begin{array}{c}409 \pm 193 \\
(93.6-880)\end{array}$ & $\mathrm{Z}=0.76, \mathrm{p}=0.45$ \\
\cline { 1 - 4 } & & $\begin{array}{c}303 \pm 118 \\
(81.8-564.4)\end{array}$ & $\begin{array}{c}254 \pm 181 \\
(32.8-407)\end{array}$ & $\mathrm{Z}=1.82, \mathrm{p}=0.07$ \\
\hline
\end{tabular}

contaminated with heavy metals, are also characterized by a high energy value comparable to brown coal (Table 5). Due to the high biomass of the aboveground parts and high energy value of the goldenrod, the possibility of using the plant for energy purposes was indicated [e.g. Biskupski et al. 2012, Patrzałek et al. 2012].

There is relatively little research on the content of metals in individual morphological parts of the goldenrod. The research carried out by Nowińska et al. [2012] on the accumulation of selected heavy metals $(\mathrm{Pb}, \mathrm{Zn}, \mathrm{Hg})$ in the aboveground Solidago parts collected from the flotation settler of zinc and lead ores as well as the coal mining waste dump showed a relatively low metal content in the examined parts of the plant. In turn, Antonijevic et al. [2012] reported that $S$. canadensis occurring in a region heavily contaminated with metals (Copper Mining and Smelting Complex Bor in Serbia) accumulates individual metals in various proportions in the aboveground and underground parts. For example, the
$\mathrm{Zn}$ content in the aboveground goldenrod parts is comparable to its content in the roots, the $\mathrm{Mn}$ content is higher in the aboveground parts than in the roots, while the $\mathrm{Cu}$, $\mathrm{As}$ and $\mathrm{Pb}$ contents are higher in the roots than the stems and leaves. Similarly, Antonijevic et al. [2012] and Yang et al. [2008] indicate a high accumulation of $\mathrm{Pb}$ in roots and rhizomes of $S$. canadensis. The authors report that the ratio of the $\mathrm{Pb}$ content in underground $S$. canadensis parts to the aboveground parts is 31 at $300 \mathrm{mg} \mathrm{Pb} / \mathrm{kg}$ soil, and 110 at 600 $\mathrm{mg} \mathrm{Pb} / \mathrm{kg}$ soil. Xiang et al. [2010] emphasize the role of roots of $S$. canadensis as an accumulator of lead. Similarly, Majtkowski et al. [2011] determined a higher accumulation of $\mathrm{Pb}$ and $\mathrm{Cr}$ in the roots than the aboveground parts of $S$. canadensis collected in the area contaminated with sewage sludge from the wastewater treatment plant in Bydgoszcz (Poland). The research conducted by Tomiyasu et al. [2005] showed that the Solidago roots accumulate far more $\mathrm{Hg}$ than its stems and leaves. Fu et al. [2017] identified S. canadensis as

Table 4. Comparison of the biomass of aboveground goldenrod parts with the biomass of other plant species used for remediation and energy purposes

\begin{tabular}{|c|c|c|}
\hline Species of plant & $\begin{array}{c}\text { Reference field } \\
\text { [tons dry mater/ha] }\end{array}$ & References \\
\hline \multirow{2}{*}{ Solidago canadensis } & $4.4(\max -11.4)$ & In this paper \\
\hline & 3.3 & Jezierska- Domaradzka and Domaradzki [2012] \\
\hline Miscantus $\mathrm{x}$ giganteus & $10(\max -25)$ & \multirow{3}{*}{ Kabała et al. [2010] } \\
\hline Helianthus tuberosus & 8 & \\
\hline Sida hermaphrodita & $9(\max -25)$ & \\
\hline Calamagrostis epigejos & $4,03-4,47$ & Grzelak et al. [2016] \\
\hline
\end{tabular}

Table 5. Heating value of brown coal and selected plant species

\begin{tabular}{|l|c|l|}
\hline \multicolumn{1}{|c|}{ Charge } & Heating value [MJ.kg-1 d.m.] & \multicolumn{1}{|c|}{ References } \\
\hline Brown coal & $21.8-30.2$ & \multirow{2}{*}{ Patrzałek et al. [2012] } \\
\hline Species of plant: & 19.3 & \\
\hline Solidago sp. & 19.5 & Godin et al. [2013] \\
\hline Miscantus $\times$ giganteus & 17.6 & Lisowski et al. [2018] \\
\hline Helianthus tuberosus & 14.4 & Grzelak et al. [2016] \\
\hline Sida hermaphrodita & 17,5 & \\
\hline Calamagrostis epigejos & &
\end{tabular}


a plant tolerant to cadmium accumulation and a potential species for phytoremediation.

According to the presented literature, due to a very extensive root system (Photo 1), goldenrod tends to accumulate more of some metals, e.g. $\mathrm{Pb}$ in roots than in its aboveground parts.

The literature lacks the information on the metals content in rhizomes of the plant. Our research shows that rhizomes make up about $70 \%$ of the biomass of underground parts of $S$. canadensis. With roots they can play a significant role in the accumulation of some metals. In addition, an extensive underground system can play a stabilizing role and prevent the erosion of soil which is especially important in landfills containing large amounts of metals.

The results of the studies showed that such parameters as density and the percentage cover of plots with $S$. canadensis have no effect on the biomass of the aboveground and underground parts of the goldenrod and the height of its ramets. The goldenrod biomass is also not affected by the time of goldenrod occurrence at the sites. In the areas overgrown by the goldenrod (including contaminated sites e.g. landfills), the plant may create a protective barrier for the areas adjacent to it.

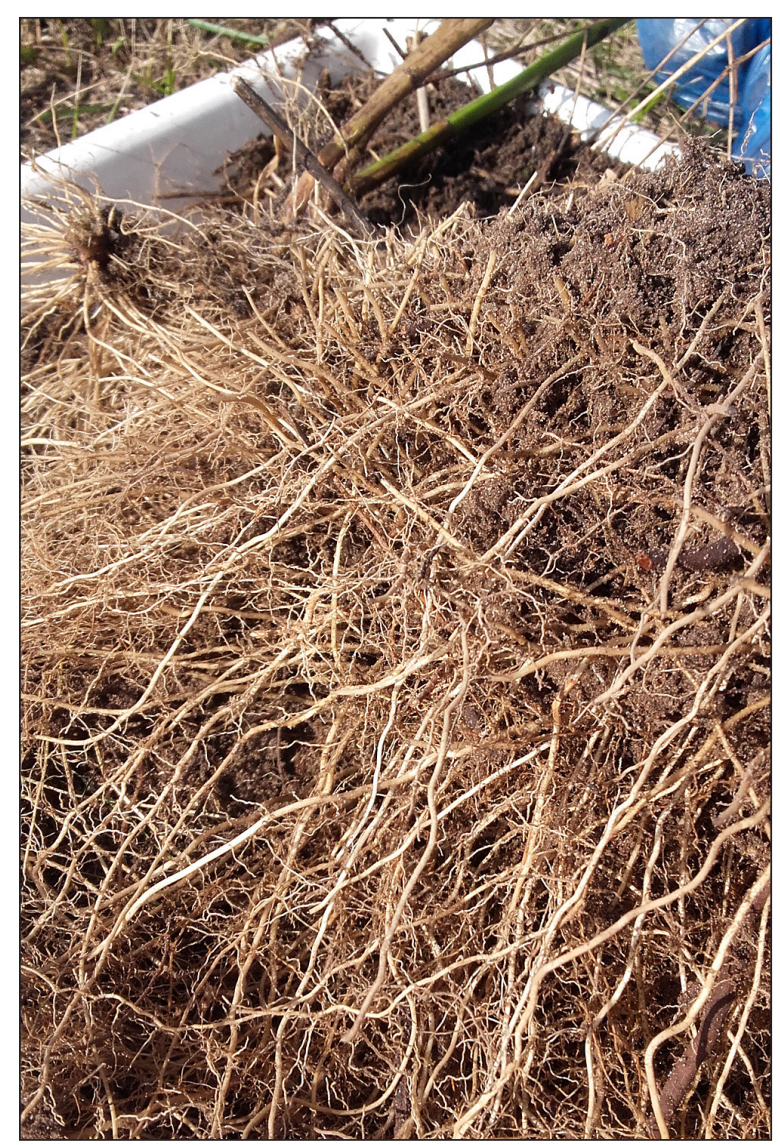

Photo 1. Underground parts of Solidago canadensis

\section{CONCLUSIONS}

The features of Solidago canadensis that predispose the plant for the phytoremediation purposes are:

- high tolerance to heavy metals soil contamination;

- high biomass of the aboveground parts, comparable to the biomass of other plant species used in phytoremediation;

- possibility of annual harvesting of the aboveground parts and their high energy value comparable to other plant species used in phytoremediation;

- extensive roots and rhizomes system that stabilizes the soil and provides protection against erosion.

Due to high accumulation of selected metals in the roots, the Canadian goldenrod can be considered as a metal phytostabilizer (e.g. $\mathrm{Pb}, \mathrm{Cr}$, $\mathrm{Hg}$ ) in contaminated soils.

\section{REFERENCES}

1. Antonijevic M.M., Dimitrijevic M.D., Milic S.M., Nujki M.M. 2012. Metal concentrations in the soils and native plants surrounding the old flotation tailings pond of the Copper Mining and Smelting Complex Bor (Serbia), Journal of Environmental Monitoring 14, 866-877 DOI: $10.1039 / \mathrm{c} 2 \mathrm{em} 10803 \mathrm{~h}$

2. Biskupski A., Rola J., Sekutowski T., Kaus A., Włodek S. 2012. Wstępne wyniki dotyczące technologii zbioru biomasy Solidago $s p$. i jej przetwarzania do celów opałowych, Zeszyty Naukowe Uniwersytetu Przyrodniczego we Wrocławiu, 584, 7-15.

3. Fu W., Huang K., Cai H.H., Li J., Zhai D.L., Dai Z.C., Du D.L. 2017. Exploring the potential of naturalized plants for phytoremediation of heavy metal contamination. International Journal of Environmental Research, 11(4), 515-521.

4. Godin B., Lamudière S., Agneessens R., Schmit T., Goffart J.P., Stilmant D., Gerin P.A., Delcarte J., 2013. Chemical characteristics and biofuel potential of several vegetal biomasses grown under a wide range of environmental conditions. Industrial Crops and Products. 48, 1-12.

5. Grzelak M., Gaweł E., Murawski M., Waliszewska B., Knioła A. 2016. Warunki siedliskowe, plonowanie i możliwości energetyczne wykorzystania biomasy trzcinnika piaskowego (Calamagrostis epigejos). Fragmenta Agronomica, 33(3), 38-45.

6. Guzikowa M., Maycock P.F. 1986. The invasion and expansion of three North America species of goldenrod (Solidago canadensis L. sensu lato, $S$. gigantea Ati. and S. graminifolia (L.) Salisb. in 
Poland. Acta Societatis Botanicorum Poloniae, 55, 367-384. https://doi.org/10.5586/asbp.1986.034

7. Holeksa J., Błońska A., Kapała-Bąba A., Woźniak G., Kurek P., Szarek-Łukaszewska G., Grodzińska K., Żywiec M. 2015. The vegetation of the Olkusz Ore-bearing Region. In: Godzik B. (ed.) Natural and historical values of the Olkusz Ore-bearing Region. W. Szafer Institute of Botany. Polish Academy of Sciences. Kraków, 105-128.

8. Huang H., Guo S., Chen G. 2007. Reproductive biology in an invasive plant Solidago canadensis. Frontiers of Biology, 2(2),196-204.

9. Huang H., Guo S.L. 2005. Analysis of population genetic differences of the invasive plant Solidago canadensis. Bulletin Botanical Research, 25(2), 197-204.

10. Jezierska-Domaradzka A., Domaradzki K. 2012. Solidago canadensis $L$ jako potencjalny gatunek energetyczny - zagrożenie dla środowiska przyrodniczego oraz ocena naturalnych zasobów surowca na przykładzie wybranych odłogowanych pól w powiecie wołowskim na Dolnym Śląsku. Zeszyty Naukowe Uniw. Przyrodn. we Wrocławiu, Rolnictwo C, 524: 43-52.

11. Jin L., Gu Y., Xiao M., Chen J.K., Li B. 2004. The history of Solidago canadensis invasion and the development of its mycorrhizal associations in newly-reclaimed land, Functional Plant Biology, 31, 979-986.

12. Kabała C., Karczewska A., Kozak M. 2010. Przydatność roślin energetycznych do rekultywacji i zagospodarowania gleb zdegradowanych. Zeszyty Naukowe Uniwersytetu Przyrodniczego we Wrocławiu, Rolnictwo, 576, 97-118.

13. Laghlimi M., Baghdad B., El Hadi H., Bouabdli A. 2015. Phytoremediation Mechanisms of Heavy Metal Contaminated Soils: A Review. Open Journal of Ecology 5(8), ID: 5883210.4236/oje.2015.58031.

14. Lisowski J., Borusiewicz A., Porwisiak H. 2018. Porównanie plonowania, ciepła spalania i wartości opałowej ślazowca pensylwańskiego (Sida hermaphrodita L.) z miskantem olbrzymim (Miscanthus $\times$ giganteus $)$ uprawianych na terenie województwa Podlaskiego. Fragmenta Agronomica, 35(1), 53-61. DOI: 10.26374/fa.2018.35.05

15. Majtkowski W., Golimowski R., Boroń M., Szulc P.M. 2011. Rekultywacja pól irygowanych w Bydgoszczy z wykorzystaniem metody fitoremediacji. Problemy Inżynierii Rolniczej, 2, 177-184.

16. Nowińska K., Kokowska-Pawłowska M., Patrzałek A. 2012. Metale w Calamagrostis Epigejos i Solidago $S p$. ze zrekultywowanych nieużytków poprzemysłowych, Infrastruktura i Ekologia Terenów Wiejskich, nr 3, 91-100.

17. Patrzałek A., Kokowska-Pawłowska M., Nowińska K. 2012. Wykorzystanie roślin dziko rosnących do celów energetycznych. Górnictwo i Geologia 7(2), 177-185.

18. Rola J., Rola H. 2010. Solidago spp. biowskaźnikiem występowania odłogów na gruntach rolnych, Fragmenta Agronomica, 27(3),122-131.
19. Rzymowska Z., 2015. Nasilenie występowania Solidago canadensis L. w zachwaszczeniu upraw w granicach miasta Siedlce i na obszarach podmiejskich, Zeszyty Naukowe Uniwersytetu Przyrodniczo-Humanistycznego w Siedlcach, seria Rolnictwo, 1(1): 29-44

20. Salt D.E., Blaylock M., Kumar N.P., Dushenkov V., Ensley B.D., Chet I., Raskin I. 1995. Phytoremediation: a novel strategy for the removal of toxic metals from the environment using plants, Nature Biotechnology, 13, 468-474.

21. Sinha S., Mishra R.K., Sinam G., Mallick S., Gupta A.K. 2013. Comparative evaluation of metal phytoremediation potential of trees, grasses and flowering plants from tannery wastewater contaminated soil in relation with physico-chemical properties. Soil and Sediment Contamination: An International Journal, 22, 958-983.

22. Susarla S., Medina V. F., McCutcheon S. C. 2002. Phytoremediation: An ecological solution to organic chemical contamination. Ecological Engineering, 18, 647-658.

23. Szymura M., Wolski K. 2006. Zmiany krajobrazu pod wpływem ekspansywnych bylin północno amerykańskich z rodzaju Solidago L. Regionalne Studia Ekologiczno-Krajobrazowe, Problemy Ekologii Krajobrazu 16(1), 451-460.

24. Thangavel P., Subhuram C.V. 2004. Phytoextraction - Role of hyper accumulators in metal contaminated soils. Proceedings of the Indian National Science Academy. Part B, 70(1), 109-130.

25. Tomiyasu T., Matsuo T., Miyamoto J., Imura R., Anazawa K., Sakamoto H. 2005. Low level mercury uptake by plants from natural environments-mercury distribution in Solidago altissima L., Environmental Sciences, 12, 231-238.

26. Vega F.A., Covelo E.F., Andrade M.L., Marcet P. 2004. Relationships between heavy metals content and soil properties in minesoils, Analytica Chimica Acta, 524, 141-150.

27. Weber E. 2000. Biological flora of Central Europe: Solidago altissima L. Flora, 195, 123-134 https:// doi.org/10.1016/S0367-2530(17)30960-X.

28. Weber E., Jacobs G. 2005. Biological flora of central Europe: Solidago gigantea Aiton. Flora, 200, 109-118.

29. Xiang Y.C., Feng T., Liu B.G., Chen Y. 2010. Growth and accumulation character of heavy metals for Solidago canadensis grown in amended manganese mining tailing. Mineral Energy Resources, 25(1), 63-68.

30. Yang R.Y., Yu G.D., Tang J.J., Chen, X. 2008. Effects of metal lead on growth and mycorrhizae of an invasive plant species (Solidago canadensis L.), Journal of Environmental Sciences, 20, 739-744. 